\title{
Uptake of ammonium and urea in the northeast Pacific: comparison between netplankton and nanoplankton
}

\author{
Steven A. Kokkinakis, Patricia A. Wheeler \\ College of Oceanography, Oregon State University, Corvallis, Oregon 97331, USA
}

\begin{abstract}
The stable isotope ${ }^{15} \mathrm{~N}$ was used to measure nitrogen uptake in the coastal upwelling region off Oregon and Washington, USA, where nitrate concentrations in the surface water ranged from 0.7 to $49.1 \mu \mathrm{M}$. Nanoplankton biomass ( 1 to $10 \mu \mathrm{m}$ ) was relatively more abundant at low-nitrate stations, while netplankton biomass $(10$ to $200 \mu \mathrm{m})$ was dominant at high-nitrate stations. Ammonium was more important than urea as a regenerated nitrogen source for both size classes of plankton, and ambient ammonium concentrations appeared to inhibit urea assimilation. Nanoplankton and netplankton were equally important in use of regenerated nitrogen in low-nitrate waters, while netplankton dominated nitrogen use in high-nitrate waters. In high-nitrate waters, the percent uptake in each size fraction was proportional to the percent particulate nitrogen (PN) and chlorophyll a (chl a) in that fraction. At lownitrate stations, uptake in each fraction was proportional to $\mathrm{PN}$ but not to $\mathrm{chl}$ a. Nitrogen-specific (mass $\mathrm{N}$ taken up/mass particulate $\mathrm{N}$ ) uptake rates ranged from 0.2 to $2.6 \mathrm{~d}^{-1}$, and were generally higher for the netplankton than for the nanoplankton fraction. However, these rates are not directly proportional to phytoplankton use as a result of varying amounts of non-phytoplankton $N$. Phytoplankton $N$ was estimated by assuming a constant chl a/PN ratio for each size class, and used to calculate phytoplankton-specific uptake rates. Phytoplankton growth rates were estimated by extrapolating the short-term uptake rates to daily rates. Since calculated growth rates exceeded the expected maxima for phytoplankton in the low-nitrate coastal water, we postulate heterotrophic utilization of nitrogen.
\end{abstract}

\section{INTRODUCTION}

Attempts have been made to determine specific photosynthetic rates and nutrient uptake rates of various size classes of phytoplankton. Malone (1980) reviewed a number of marine size-fractionation studies showing that netplankton tend to dominate in wellmixed, high-nitrate waters, while nanoplankton prevail in stratified, low-nitrate waters. Furthermore, size-fractionated nitrogen uptake measurements (Glibert 1982, Probyn 1985) support the conclusion that netplankton production is primarily sustained by new nitrogen (nitrogen introduced from outside the euphotic zone), while nanoplankton production is supported by regenerated nitrogen (nitrogen regenerated within the euphotic zone).

Underlying causes for the dominance of net- or nanoplankton in particular environments have not been established. Metabolic rates tend to be inversely related to size, and the data reviewed by Malone (1980) indicate a higher maximum rate of chlorophyll-specific photosynthesis by nanoplankton than by netplankton, with means of 7.12 and $3.77 \mathrm{mg} \mathrm{C} \mathrm{mg} \mathrm{chl} \mathrm{a}^{-1} \mathrm{~h}^{-1}$, respectively. Futhermore, Chan (1980) found that phytoplankton growth rates appear to be proportional to maximal photosynthetic rates per unit carbon. Although the existence of a tight coupling between maximal growth rates and cell size has been questioned (Banse 1982), 2 generalizations still appear to be valid for temperatures of 18 to $20^{\circ} \mathrm{C}$ : (1) many diatoms have doubling rates $>1 \mathrm{~d}^{-1}$ (Eppley 1977), and (2) most dinoflagellates have doubling rates $\leq 1 \mathrm{~d}^{-1}$ (Banse 1982). The ratios of $\mathrm{C} / \mathrm{Chl} \mathrm{a}$ and protein/C appear to be independent of size, but ratios are quite different for diatoms and dinoflagellates, and faster growth of diatoms may be due to the greater abundance of chl a per unit cell C (Chan 1978).

During summer 1985 , we used ${ }^{15} \mathrm{~N}$ as a tracer to study the uptake of nitrogenous nutrients by microorganisms ( 1 to $200 \mu \mathrm{m}$ ) off the Washington and Oregon coasts. In this region, spring and summer upwelling leads to cold, nutrient-rich surface water and north-tosouth bands of high productivity and biomass (Small \& Menzies 1981). Nutrient concentrations, biomass levels, and nitrate uptake rates were reported by Kokkinakis \& Wheeler (1987) and are summarized 
briefly here. Nitrate concentrations in the surface water (at 10 to $15 \mathrm{~m}$ ) were highest $(20$ to $50 \mu \mathrm{M}$ ) at nearshore shallow (50 to $300 \mathrm{~m}$ ) stations, and low (1 to $5 \mu \mathrm{M})$ at offshore deep (600 to $3000 \mathrm{~m}$ ) stations. Biomass (particulate nitrogen, $\mathrm{PN}$, and chl a) was highest at stations with intermediate nitrate concentrations in the surface water, and the ratio chl a/PN increased hyperbolically with increasing nitrate concentrations. Chain-forming diatoms (species of Asterionella, Nitzschia, and Thalassiosira) were abundant in the high-nitrate water, while smaller diatoms and flagellates were most common in low-nitrate water. Uptake of new (nitrate) nitrogen accounted for $83 \%$ ( $\mathrm{SD}=2 \%, n=5$ ) of total nitrogen uptake at the highnitrate stations but only $28 \%(\mathrm{SD}=17 \%, n=5)$ of total nitrogen uptake at low-nitrate stations. Uptake of nitrate- $N$ at stations with $>1 \mu M$ nitrate- $N$ was sufficient to support phytoplankton growth rates of 1 to $2 \mathrm{~d}^{-1}$. Inclusion of ammonium as a nitrogen source and assumption that all ammonium uptake was by phytoplankton resulted in unusually high growth rates. We suggested that heterotrophic utilization of ammonium may have caused these unusually high estimates of phytoplankton growth rates (Kokkinakis \& Wheeler 1987).

Here, we report utilization of regenerated forms of nitrogen (ammonium and urea) by 2 size classes of phytoplankton during this coastal upwelling study. Relative utilization of regenerated nitrogen is compared for low-nitrate and high-nitrate stations for each size class. The size fractionation experiments were carried out at 9 of the 16 stations sampled during the study, but uptake rates for both size fractions were determined at only 8 stations. Nitrate uptake was measured at 10 stations, but only for the $<200 \mu \mathrm{m}$ fraction. Nevertheless, the relative distribution of nitrate uptake at high-nitrate stations can be inferred from the dominance of netplankton biomass at those stations while nitrate uptake at low-nitrate stations was a minor portion of total nitrogen uptake.

Four null-hypotheses were tested: (1) Particulate nitrogen and chl a have the same relative distribution between size classes in high-and low-nitrate waters. (2) There is no difference between ammonium and urea uptake rates in high- and low-nitrate waters. (3) There is no difference between relative utilization of ammonium and urea by net- and nanoplankton. (4) All ammonium and urea uptake is by phytoplankton.

\section{METHODS}

Sampling. All experiments were conducted during July 1985 aboard RV 'Wecoma' in coastal water off Oregon and Washington, USA $\left(44\right.$ to $47^{\circ} \mathrm{N}, 124$ to $\left.126^{\circ} \mathrm{W}\right)$. Only surface water (10 to $15 \mathrm{~m}$ ) was sampled for biomass and uptake measurements. The summer mixed layer extends to $20 \mathrm{~m}$ in waters $\geq 75 \mathrm{~km}$ offshore and maximum phytoplankton biomass and photosynthesis are observed in the upper $20 \mathrm{~m}$ (Small \& Menzies 1981). Water samples were prescreened through 200 um nylon Nitex mesh for analysis of combined net- and nanoplankton biomass and activity, and additional samples were prescreened through $10 \mu \mathrm{m}$ Nitex mesh for separate analysis of nanoplankton biomass and activity (the 1 to $10 \mu \mathrm{m}$ size class for our experiments). Netplankton biomass and activity (the 10 to $200 \mu \mathrm{m}$ size class for our experiments) were calculated by subtracting $<10 \mu \mathrm{m}$ values from the $<200 \mu \mathrm{m}$ values. Results are presented separately for low-nitrate $(<5 \mu \mathrm{M})$ and high-nitrate $(\geq 20 \mu \mathrm{M})$ stations since these stations showed distinct differences in percentage of new production (Kokkinakis \& Wheeler 1987).

Light intensity was measured with a Li-Cor (Lincoln, NB, USA) Model Li-185a Quantum/Radiometer/Photometer. Light intensities between 08:00 and 15:00 h were $483 \pm 147 \mu$ Einst $\mathrm{m}^{-2} \mathrm{~s}^{-1}$ at the surface and $114 \pm$ 61 at $10 \mathrm{~m}$. Thus, light limitation of phytoplankton activity in the mixed layer was unlikely during our sampling. Incubations were carried out in $2.7 \mathrm{l}$ polycarbonate bottles covered with one layer of neutraldensity screening to reduce the sunlight intensity by $50 \%$ and placed in Plexiglas deck boxes cooled by circulating seawater.

Nutrients and biomass. Ammonium concentrations were determined manually within $1 \mathrm{~h}$ of water collection by the phenolhypochlorite reaction (Strickland \& Parsons 1972). Water samples for urea and nitrate were filtered (Whatman GF/F, nominal pore size $0.8 \mu \mathrm{m}$ ) and stored frozen in polyethylene bottles prior to analysis. Urea was determined using the urease method (McCarthy 1970) with urease enzyme (Type IV) obtained from Sigma (St. Louis, MO, USA). Nitrate and nitrite were measured colorimetrically after formation of the diazo dye (Strickland \& Parsons 1972) as adapted for AutoAnalyzer (Atlas et al. 1971).

Particulate material for chlorohyll (chl a) and nitrogen (PN) analyses was collected on $25 \mathrm{~mm}$, glass-fiber filters (Whatman GF/F) under vacuum $(<180 \mathrm{~mm} \mathrm{Hg}$ pressure differential). Filters were precombusted for PN samples, but not for chl a samples. Chl a samples were stored frozen under vacuum for 1 to $2 \mathrm{wk}$ until analyses could be performed using a Turner Designs fluorometer following procedures described by Strickland \& Parsons (1972) [mean coefficient of variation $(\mathrm{CV})$ for duplicates $=10.4 \%$. Fluorometer drift was adjusted using a coporphyrin standard, and fluorescence was calibrated with a chl a standard. Particulate nitrogen samples were stored frozen and then dried for 24 h at $60^{\circ} \mathrm{C}$. Particulate nitrogen and carbon concen- 
trations were determined using a Perkin Elmer CHN analyser (mean CV for duplicates $=3.6 \%$ ).

Uptake rates. Nitrogen uptake was determined only in the light using short-term simulated in situ incubations with ${ }^{15} \mathrm{~N}$ tracers. Additions of $0.1 \mu \mathrm{M}$ ammonium$\mathrm{N}\left(99.7\right.$ atom-\% $\left.{ }^{15} \mathrm{~N}\right)$ and $0.2 \mu \mathrm{M}$ urea-N (95.1 atom-\% ${ }^{15} \mathrm{~N}$ ) were made to separate 2.71 polycarbonate incubation bottles. Uptake was measured at approximately $10,30,60$, and $120 \mathrm{~min}$ for ammonium and at 10,60 , and 180 min for urea, with each sample being collected by filtration onto $47 \mathrm{~mm}$, precombusted glass-fiber filters (Whatman GF/F). Natural abundance of ${ }^{15} \mathrm{~N}$ in the particulate nitrogen was also determined and is used as the time zero point. Filters were frozen immediately and then dried at $60^{\circ} \mathrm{C}$ for 24 h after return to the shore-based laboratory. All dried filter samples were stored under vacuum prior to determination of isotopic enrichment. Relative abundance of ${ }^{15} \mathrm{~N}$ was determined by emission spectrometry (Fiedler \& Proksch 1975). Procedures for sample preparation were adapted from LaRoche (1983) as described by Wheeler \& Kirchman (1986). A mean standard deviation (SD) for analysis of ${ }^{15} \mathrm{~N}$ in particulate nitrogen $(0.016$ atom $\%)$ was determined empirically by averaging SD's from triplicate, single time-point estimates.

Short-term uptake rates $(\rho)$ were calculated by dividing the rate of increase of ${ }^{15} \mathrm{~N}$ in the particulate material by the atom \% enrichment of the dissolved nitrogenous nutrient and the length of the incubation period:

$$
\rho=\left\{\left[\mathrm{d}\left(\text { atom } \%{ }^{15} \mathrm{~N} \text { of } \mathrm{PN}\right) / \mathrm{dt}\right] / \mathrm{R}\right\} \times \mathrm{PN}
$$

where $\mathrm{R}=$ atom \% enrichment of ammonium or urea; PN = average amount of particulate nitrogen. Ammonium uptake rates were corrected for changes in atom \% enrichment of dissolved ammonium during the incubation period (Gilbert et al. 1982; see also below). The arithmetic average PN during each incubation was calculated from initial $\mathrm{PN}$ plus nitrogen taken up (nitrate, ammonium, and urea) during the incubation. The average increase in particulate nitrogen calculated from the summed uptake of 3 nitrogenous nutrients was 2 and $6 \%$ per $h$, respectively, for nano- and netplankton

Ammonium regeneration was determined by isotope dilution (Harrison 1978, 1983, Glibert et al. 1982). No significant isotope dilution occurred at Stns 4, 6, 10 , and 12 . For the remaining stations, significant isotope dilution did occur and the exponential mean atom $\%$ ${ }^{15} \mathrm{~N}$ of dissolved ammonium was used to calculate uptake rates (Glibert et al. 1982). The ratio of corrected/uncorrected ammonium uptake rates at these stations ranged from 1.10 to 2.39 , averaging 1.65 (Kokkinakis \& Wheeler 1987). Mass balance calculations for the ammonium uptake experiments are reported by Kokkinakis (1987), and indicate that more ammonium left the dissolved pool than was accumulated in the particulate fraction. Thus, the rates reported here are likely to underestimate ammonium utilization

Daily (24 h) nitrogen-specific uptake rates were calculated using short-term uptake rates. The mid-morning and mid-afternoon uptake rates were assumed to be representative for the entire photoperiod, i. e. $15 \mathrm{~h}$. Dark ammonium uptake rates were assumed to be $52 \%$ of the measured light uptake rates, while dark urea uptake was assumed to be $27 \%$ of light uptake. These estimates are based on the mean of ratios reported by Price et al. (1985) for the Strait of Georgia, British Columbia, Canada. Turnover times for ammonium and urea were calculated as follows:

turnover time $=$ [ambient + tracer nutrient conc.] $/$ uptake rate.

A relative preference index (RPI) (McCarthy et al. 1977) was used to compare the utilization of ammonium and urea relative to their availability during the incubations. For example, for ammonium:

$$
\mathrm{RPI}_{\mathrm{NH}_{4}^{+}}=\frac{\frac{\mathrm{P}_{\mathrm{NH}_{4}^{+}}}{\mathrm{P}_{\mathrm{NH}_{4}^{+}}+\mathrm{P}_{\text {urea }}}}{\frac{\left[\mathrm{NH}_{4}^{+}\right]}{\left[\mathrm{NH}_{4}^{+}\right]+[\text {urea }]}}
$$

where $\mathrm{P}_{\mathrm{NH}_{4}^{+}}$and $\mathrm{P}_{\text {urea }}=$ absolute uptake rates $(\mu \mathrm{mol} \mathrm{N}$ $1^{-1} \mathrm{~h}^{-1}$ ) for each nutrient; $\left[\mathrm{NH}_{4}^{+}\right]$and [urea] = respective concentrations ( $\mu \mathrm{mol} \mathrm{N} \mathrm{l}^{-1}$ ).

Phytoplankton growth estimated from uptake rates. The portion of particulate nitrogen present as phytoplankton was estimated by assuming a constant chl a/ cell $\mathrm{N}$ for phytoplankton. Nitrogen specific uptake rates were multiplied by the calculated amount of phytoplankton nitrogen in each fraction to determine phytoplankton specific uptake rates per hour. Daily rates were calculated from short-term uptake rates as described above. Maximum phytoplankton growth rates $(\mu)$ were calculated by assuming that all measured assimilation of nitrogen was by phytoplankton and using the equation: $\mu=3.32 \log _{10}\left[\left(\mathrm{PPN}_{0}+\Delta \mathrm{PPN}\right) /\right.$ $P P N_{0}$ ], where $P P N_{0}$ is the estimated initial phytoplankton nitrogen, and $\triangle P P N$ is the daily increase in phytoplankton nitrogen calculated from the measured uptake rates.

\section{RESULTS}

\section{Nutrient and biomass levels}

Nitrate concentrations at Stns 2, 4, 6, 8 and 12 ranged from 0.7 to $4.6 \mu \mathrm{M}$ and these stations are designated 'low-nitrate' stations herein. Nitrate concentrations at 
Stns 1 and 10 to 12 ranged from 20.1 to $49.1 \mu \mathrm{M}$ and these stations are designated 'high-nitrate'. For all stations, ammonium concentrations ranged from undetectable to $1.23 \mu \mathrm{M}$ and urea concentrations ranged from undetectable to $0.35 \mu \mathrm{M}$. There was no significant difference between concentrations of ammonium and urea at high-and low-nitrate stations (data not shown), but urea concentrations tended to be negatively correlated with ammonium concentrations (Fig. 1).

Particulate nitrogen and chl a concentrations for the 2 size fractions are shown in Fig. 2. The average percent PN in nanoplankton was markedly higher in the low-nitrate waters than in high-nitrate waters (80 and $35 \%$, respectively), while the reverse was true for netplankton ( 20 and $65 \%$, respectively). The distribution of chl a between net- and nanoplankton at the lownitrate stations was more variable; however, the percent $\mathrm{chl} a$ in the netplankton fraction was dominant $(80.5 \%)$ at high-nitrate stations. For both size classes of plankton, chl a/PN ratios increased as nitrate concentrations increased and reached an average level of 1.83

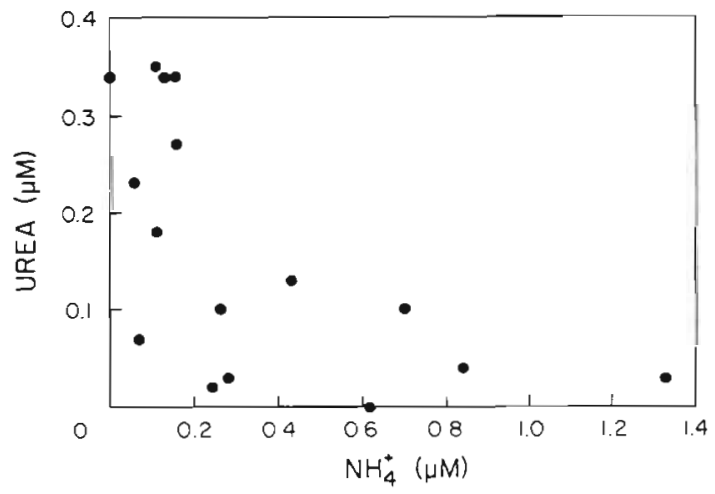

Fig. 1. Relationship between surface water concentrations of urea and ammonium for all stations \pm 0.28 (mean $\pm \mathrm{SD}$ ) for netplankton and of $0.84 \pm 0.21$ (maximum \pm standard error) for nanoplankton (Fig. 3).

\section{Uptake and turnover times of ammonium and urea}

Rates of accumulation of ${ }^{15} \mathrm{~N}$ in particulate nitrogen were constant for about 30 to $60 \mathrm{~min}$, then decreased by 30 to $60 \%$ (Fig. 4). This apparent decrease in rate of labeling results from a combination of substrate depletion (mean $\mu$ mol $\mathrm{NH}_{4}^{+}$taken up $\mathrm{l}^{-1} \mathrm{~h}^{-1}$ was $18 \%$ of initial concentration) and isotope dilution (see above). To minimize errors introduced by changes in $\mathrm{NH}_{4}^{+}$ concentration, rates were calculated from the initial slope of the time course data. At least 3 points were used for each rate estimate. It should be noted that these 'initial' rates are constant during the first 30 to 60 min of the incubation period and are not equivalent to

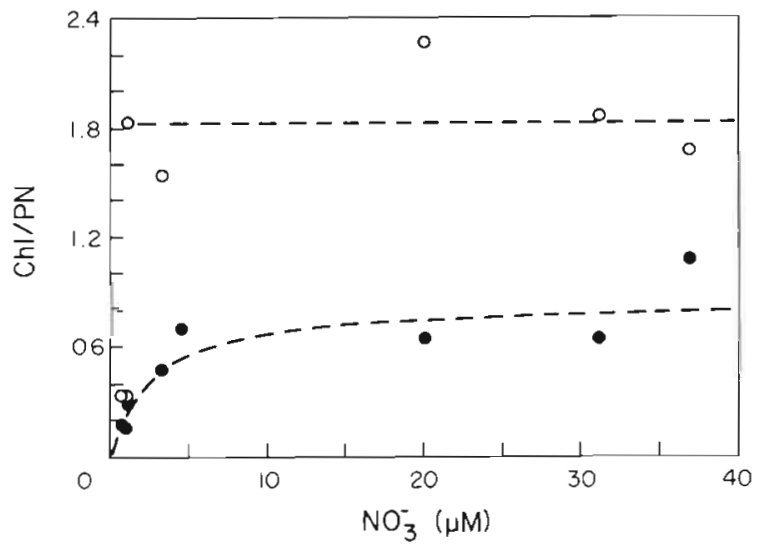

Fig. 3. Chl/PN $(\mu \mathrm{g} / \mu \mathrm{mol})$ as a function of nitrate concentrations. (o) Netplankton; dashed line: mean of values $\geq 1.5 \mu \mathrm{M}$ $\mathrm{NO}_{3}^{-}$. Nanoplankton; dashed curve determined from the Eadie-Hofstee linear transformation
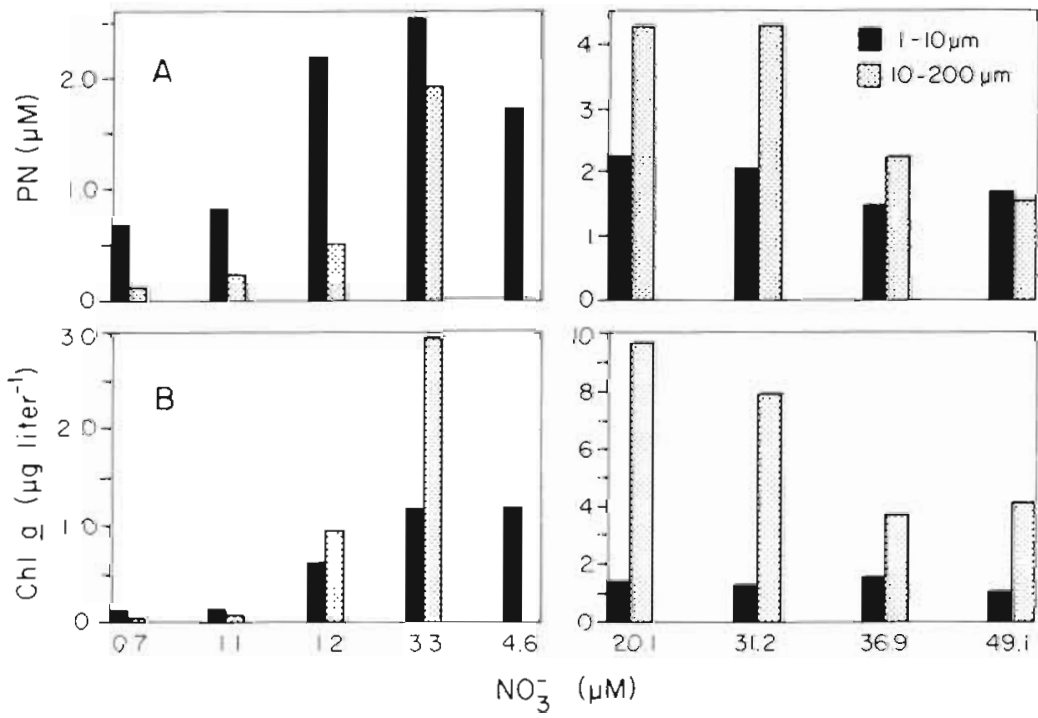

Fig. 2. (A) Particulate nitrogen (PN) concentrations for nano- (1 to $10 \mu \mathrm{m})$ and netplankton (10 to $200 \mu \mathrm{m}$ ) fractions. (B) Chl a concentration for nano- and netplankton. Labels on the $x$-axis denote nitrate concentrations at each station. (Note different scales for low- and high-nitrate stations) 
the very short-term 'surge' uptake rates reported by other investigators (e. g. Wheeler et al. 1982, Goldman \& Glibert 1983).
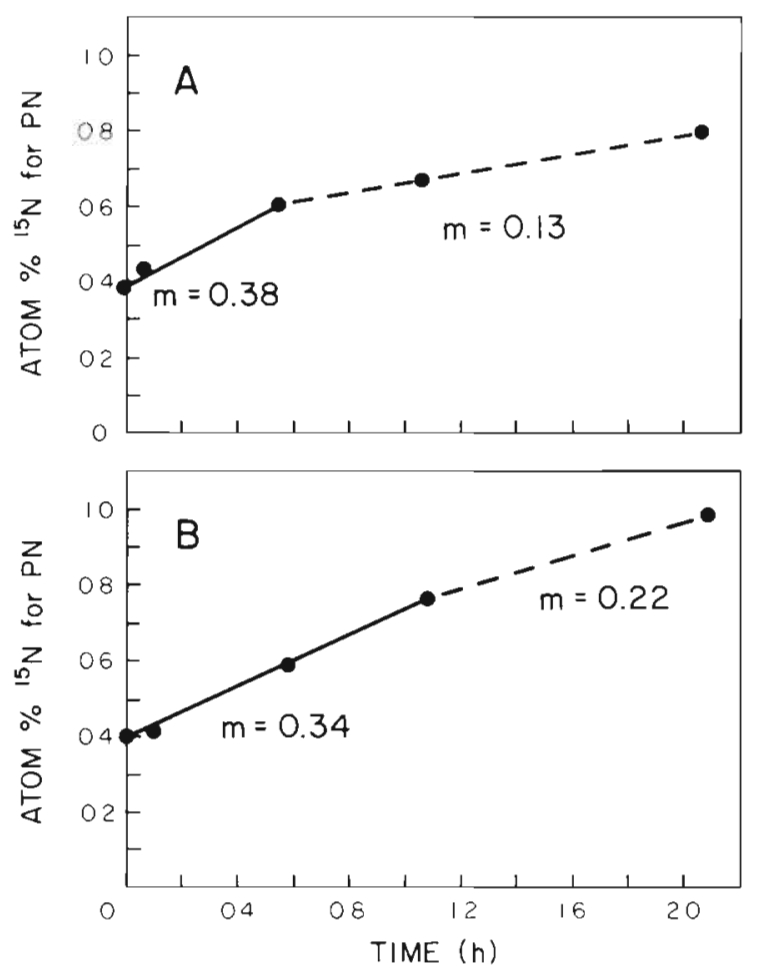

Fig. 4. Typical time course data for ammonium uptake. (A) Stn 0 (uptake rates in Kokkinakis \& Wheeler 1987). (B) Stn 1. Slopes (atom $\%{ }^{15} \mathrm{~N} \mathrm{~h}^{-1}$ ) are indicated for the initial linear portion of uptake (solid line) and the subsequent, slower portion (dashed line)
Uptake of ammonium ranged from 0.013 to $0.14 \mu \mathrm{mol}$ $\mathrm{N}^{-1} \mathrm{~h}^{-1}$ (Table 1), but showed no consistent relationship to ambient nitrate concentrations. Urea uptake rates were usually lower and ranged from 0 to 0.07 umol $\mathrm{N} \mathrm{l}^{-1} \mathrm{~h}^{-1}$ (Table 1). Uptake of both forms of regenerated nitrogen normalized to chl a were very low in high-nitrate waters and were negatively correlated with nitrate in low-nitrate waters (Fig. 5). Urea uptake measurements were made for both trace and saturating additions (0.2 and $2.0 \mu \mathrm{M}$ urea-N) at 6 stations. The ratio of saturating/trace uptake ranged from 0.4 to 1.7 , with a mean value of 1.0 (data not shown). The ratio of saturating/trace ammonium uptake was not measured during this study, but during 1984 ranged from 1.04 to 1.77, with a mean value of 1.41 (4 sampling dates between 18 June and 8 August during the upwelling season with nitrate levels ranging from 6 to $27 \mu \mathrm{M}$ ) for water samples collected $10 \mathrm{~km}$ offshore (Wheeler unpubl.).

Turnover times - time required for the plankton to completely utilize the dissolved pool (ambient conc. + tracer addition), of a particular nitrogenous nutrient were significantly lower for ammonium than for urea (Fig. 6). Mean values were 0.37 and $1.58 \mathrm{~d}$ for ammonium and urea respectively, when the abnormally high values measured at Stn 14 (where nitrate concentrations were $4.6 \mu \mathrm{M}$ ) were excluded. There was no significant difference between turnover times at high-and low-nitrate stations. The ratio of urea/(urea + ammonium) uptake increased with increasing ambient urea concentrations for netplankton (Fig. 7A), and was negatively correlated with increasing

Table 1. Uptake of ammonium and urea by nano- and netplankton. Values in parentheses occurred when no biomass was present in the netplankton size class, and are not included for calculations of means

\begin{tabular}{|c|c|c|c|c|c|c|c|}
\hline \multirow[t]{2}{*}{ Stn } & \multirow{2}{*}{$\begin{array}{l}\mathrm{NO}_{3}^{-} \\
(\mu \mathrm{M})\end{array}$} & \multicolumn{2}{|c|}{ 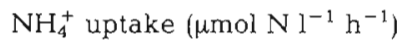 } & \multicolumn{2}{|c|}{ Urea uptake ( $\left.\mu \mathrm{mol} \mathrm{N}^{-1} \mathrm{~h}^{-1}\right)$} & \multicolumn{2}{|c|}{$\%$ Regenerated uptake } \\
\hline & & Nano & Net & Nano & Net & Nano & Net \\
\hline \multicolumn{8}{|c|}{ Low nitrate } \\
\hline 4 & 0.7 & 0.011 & 0.008 & 0.005 & 0.007 & 51.6 & 48.4 \\
\hline 8 & 1.1 & 0.016 & 0.019 & 0.008 & 0.000 & 55.8 & 44.2 \\
\hline 2 & 1.2 & 0.047 & 0.032 & 0.030 & 0.042 & 51.0 & 49.0 \\
\hline 6 & 3.3 & 0.034 & 0.064 & 0.005 & 0.015 & 33.1 & 66.9 \\
\hline \multirow[t]{3}{*}{14} & 4.6 & 0.013 & $(0.000)$ & 0.002 & $(0.000)$ & $(100.0)$ & $(0.0)$ \\
\hline & Mean & 0.024 & 0.031 & 0.010 & 0.016 & 47.9 & 52.1 \\
\hline & $\mathrm{SD}$ & 0.016 & 0.024 & 0.011 & 0.018 & 10.1 & 10.1 \\
\hline \multicolumn{8}{|c|}{ High nitrate } \\
\hline 10 & 20.1 & 0.018 & 0.072 & 0.002 & 0.018 & 18.2 & 81.8 \\
\hline 11 & 31.2 & 0.012 & 0.125 & 0.002 & 0.017 & 9.0 & 91.0 \\
\hline 12 & 36.9 & 0.014 & 0.012 & 0.004 & 0.017 & 38.3 & 61.7 \\
\hline \multirow[t]{3}{*}{1} & 49.1 & $\mathrm{NA}^{\circ}$ & NA & NA & NA & NA & NA \\
\hline & Mean & 0.015 & 0.070 & 0.003 & 0.017 & 21.8 & 78.2 \\
\hline & $\mathrm{SD}$ & 0.003 & 0.057 & 0.001 & 0.001 & 15.0 & 15.0 \\
\hline
\end{tabular}



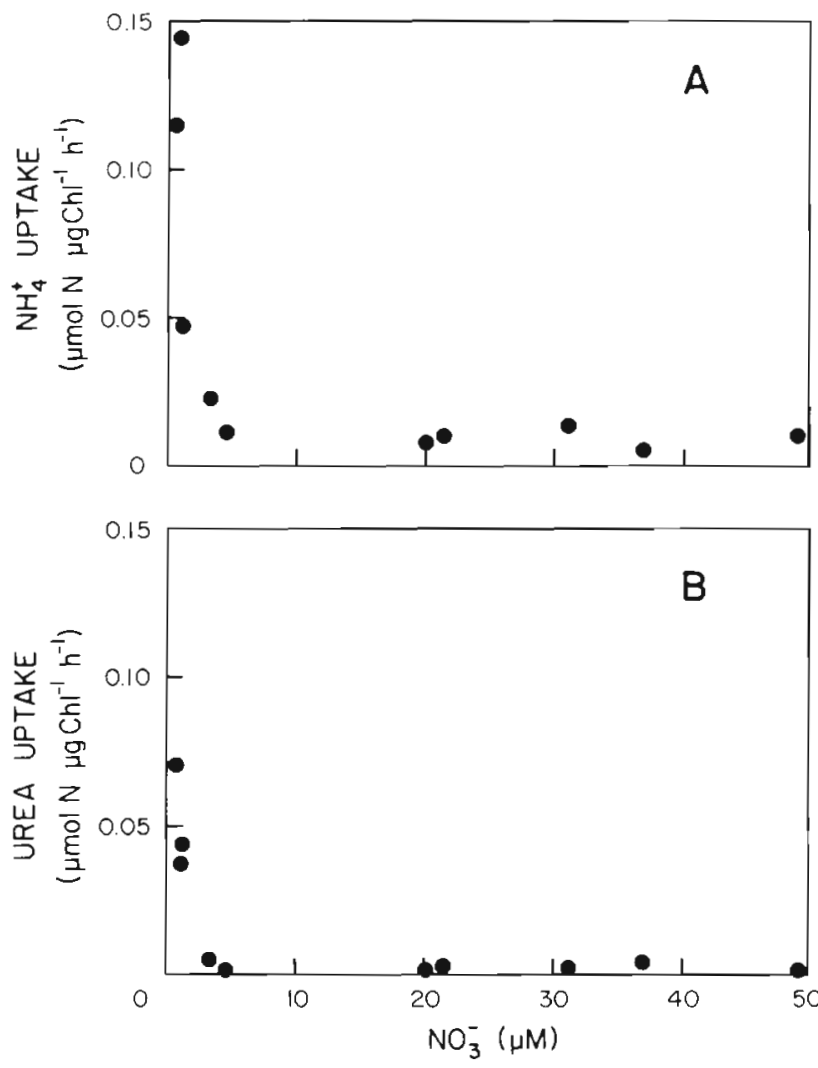

Fig. 5. Uptake rates for the $<200 \mu \mathrm{m}$ fraction as a function of ambient nitrate

ammonium concentration for both net- and nanoplankton (Fig. 7B). No significant correlation between urea/ (urea + ammonium) uptake and urea concentration was observed for nanoplankton (data not shown).

\section{Size fractionation of ammonium and urea uptake}

In low-nitrate waters, uptake of regenerated nitrogen (ammonium plus urea) was nearly equal for both size classes (Table 1). In high-nitrate waters, netplankton

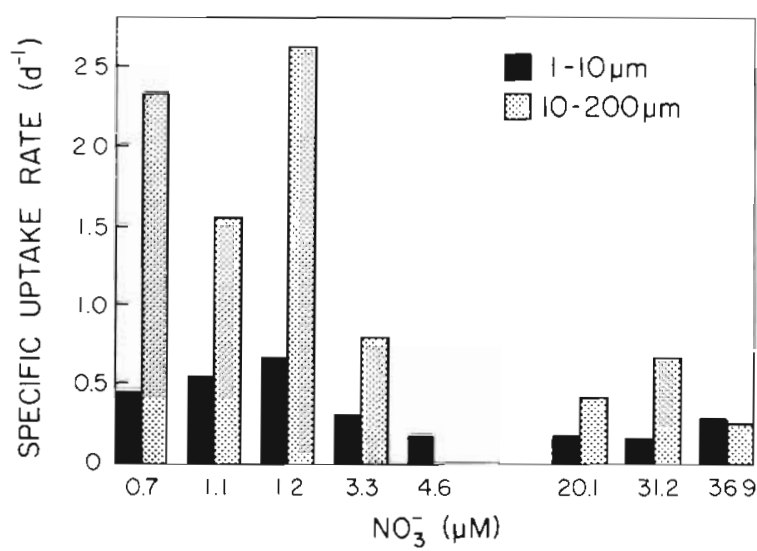

Fig. 6. Turnover times for ammonium and urea (ambient + tracer addition). Labels of the $x$-axis denote nitrate concentrations at each station

clearly dominated regenerated nitrogen use $178.2 \%$ of ammonium plus urea uptake) (Table 1), and the percent uptake of the 2 moities in each size fraction was directly proportional to the percent $P N$ and the percent chl $a$ in that fraction (Fig. 8A, B). At low-nitrate stations, uptake was directly proportional to PN biomass, however the $x$-intercept of the linear regression was different for each size class (Fig. 8C). There was no significant relationship between percent uptake and percent chl a biomass for the low-nitrate stations (Fig. 8D).

A relative preference index (RPI) for ammonium and urea was calculated for each size fraction (Table 2). Ambient plus tracer concentrations of ammonium and urea were used in the calculations, since tracer additions frequently made up a significant portion of the nutrient present and RPI cannot be determined for ambient concentrations near nutrient detection limits. The RPI values for ammonium were always $>1$ while those of urea were always less than one. Results indicate a consistent preference for ammonium, and discrimination against urea utilization relative to their respective availabilities
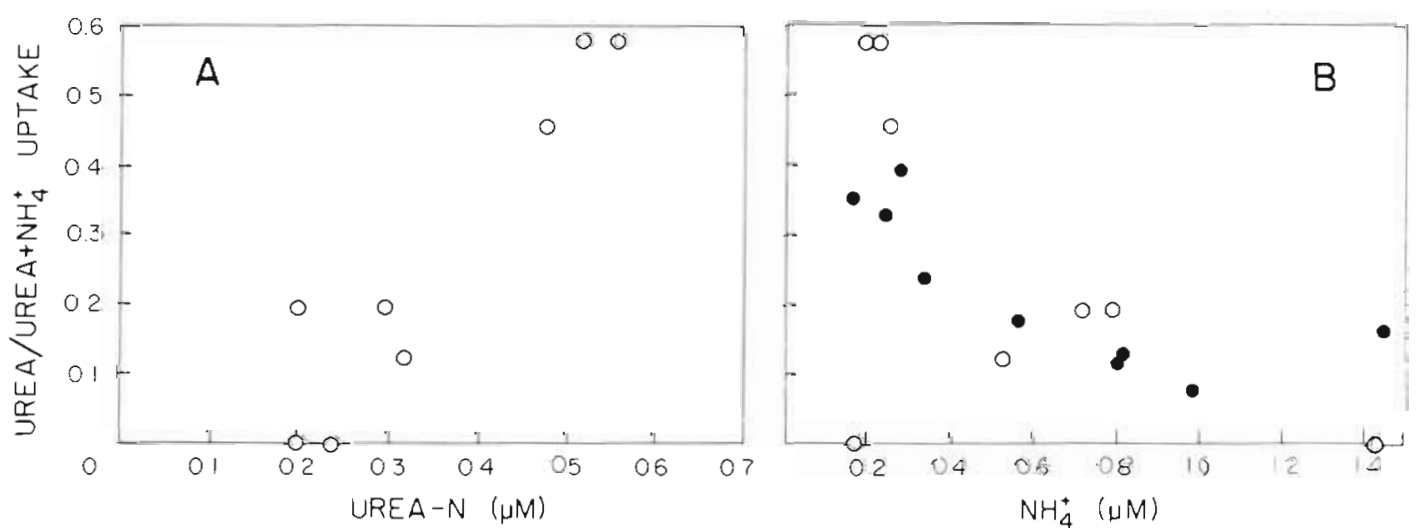

Fig. 7 (A) Ratio of urea/(urea + ammonium) uptake as a function of ambient urea-N for netplankton. (B) Ratio of urea/(urea + ammonium) uptake as a function of ambient ammonium for netplankton () and nanoplankton (•) 

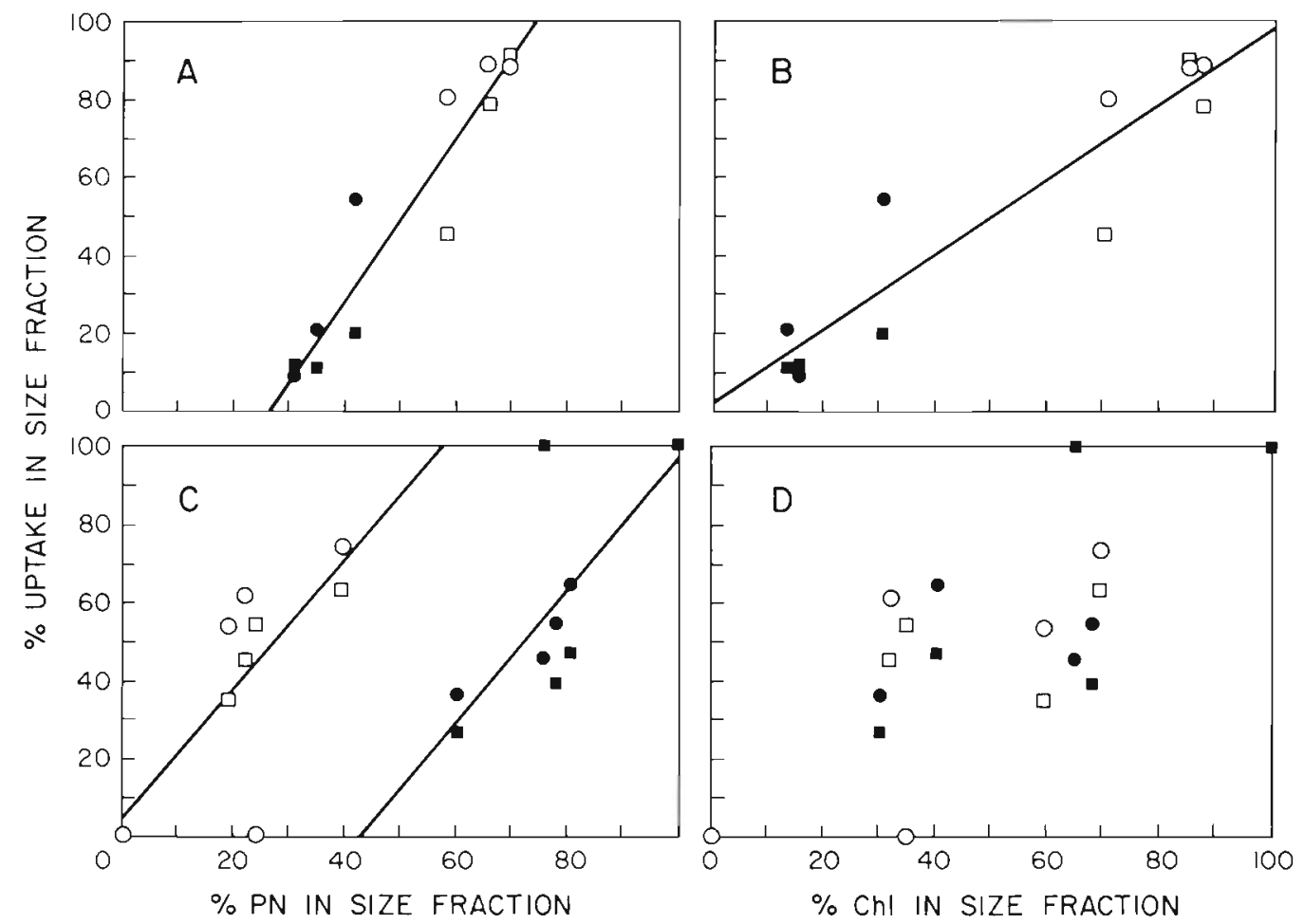

Fig. 8. Percent uptake (from values given in Table 1) as a function of percent biomass in each size fraction. (A and B) High-nitrate stations. (C and D) Low-nitrate stations. $(\square,-)$ Ammonium uptake; $(0, \bullet)$ urea uptake; open symbols: netplankton; closed symbols: nanoplankton

\section{Nitrogen-specific uptake rates}

Daily, nitrogen-specific uptake rates I(mass $\mathrm{N}$ taken up/mass $N$ present) $d^{-1}$ ] for regenerated forms of nitro-

Table 2. Relative preference index (RPI) for size-fractionated ammonium and urea uptake. All calculations are for ambient plus tracer nutrient concentrations, and thus reflect physiological preferences at these concentrations rather than in situ uptake rates

\begin{tabular}{|lcccc|}
\hline \multirow{2}{*}{ Stn } & \multicolumn{3}{c}{ Nanoplankton } & \multicolumn{2}{c|}{ Netplankton } \\
& $\mathrm{NH}_{4}^{+}$ & Urea & $\mathrm{NH}^{+}$ & Urea \\
\hline Low nitrate & & & & \\
4 & 2.2 & 0.4 & 2.0 & 0.6 \\
8 & 2.1 & 0.5 & 2.2 & 0.0 \\
2 & 3.2 & 0.5 & 2.1 & 0.7 \\
6 & 1.1 & 0.6 & 1.0 & 0.9 \\
14 & 1.2 & 0.5 & $\cdot$ & $\cdot$ \\
Mean & 2.0 & 0.5 & 1.8 & 0.6 \\
SD & 0.9 & 0.1 & 0.6 & 0.4 \\
High nitrate & & & & \\
10 & 1.1 & 0.5 & 1.2 & 0.6 \\
11 & 1.4 & 0.4 & 1.6 & 0.3 \\
12 & 2.9 & 0.3 & 2.2 & 0.7 \\
Mean & 1.8 & 0.4 & 1.7 & 0.5 \\
SD & 1.0 & 0.1 & 0.5 & 0.2 \\
All uptake occurred in the 1 to 10 um fraction & \\
\hline \multicolumn{5}{l}{} \\
\hline
\end{tabular}

gen (ammonium and urea) are about 2 to 3 times higher in the netplankton fraction than in the nanoplankton fraction in both low- and high-nitrate waters (Fig. 9). Nitrogen-specific uptake rates underestimate phytoplankton activity as a result of presence of non-phytoplankton $N$. We estimated the portion of PN present as phytoplankton by assuming that the mean values, 1.83 and 0.84 , were good approximations of chl/cell $\mathrm{N}$ for net- and nanoplankton, respectively, at high-nitrate stations. On this basis, phototrophic nanoplankton

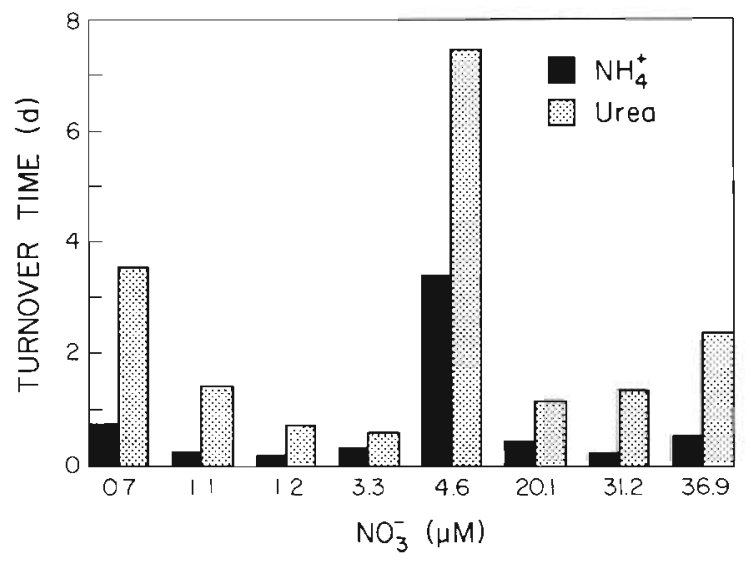

Fig. 9. Nitrogen-specific uptake rates $\left(\mathrm{d}^{-1}\right)$ for regenerated nitrogen sources for nano- and netplankton. Labels on the $x$ axis denote ambient nitrate at each station 
accounted for an average of $35 \%$ of particulate nitrogen in both regions and phototrophic netplankton accounted for 13 and $68 \%$ of particulate nitrogen in low- and high-nitrate waters, respectively (Table 3 ).

\section{Phytoplankton growth rates}

Estimates of ammonium-supported and ureasupported phytoplankton-specific growth rates range from 0.16 to $3.64 \mathrm{~d}^{-1}$ and 0.03 to $2.83 \mathrm{~d}^{-1}$, respectively,

Table 3. Estimates of phytoplankton N (PPN) for each size class

\begin{tabular}{|cccccc|}
\hline Stn & $\begin{array}{c}\text { PN } \\
(\mu M)\end{array}$ & $\begin{array}{c}\text { Net- } \\
\text { PPN } \\
(\mu \mathrm{M})\end{array}$ & $\begin{array}{c}\text { Nano- } \\
\text { PPN } \\
(\mu \mathrm{M})\end{array}$ & $\begin{array}{r}\text { Net- } \\
\text { PPN } \\
(\% \mathrm{PN})\end{array}$ & $\begin{array}{r}\text { Nano- } \\
\text { PPN } \\
(\% \mathrm{PN})\end{array}$ \\
\hline 4 & 0.80 & 0.02 & 0.14 & 2.7 & 17.9 \\
8 & 1.08 & 0.04 & 0.17 & 4.0 & 15.4 \\
2 & 2.71 & 0.52 & 0.75 & 19.2 & 27.7 \\
6 & 4.45 & 1.61 & 1.41 & 36.2 & 31.8 \\
14 & 1.74 & 0.02 & 1.43 & 0.9 & 82.6 \\
Mean & & & & 12.6 & 35.1 \\
SD & & & & 15.1 & 27.4 \\
10 & 6.51 & 5.30 & 1.69 & 81.4 & 26.0 \\
11 & 6.35 & 4.36 & 1.57 & 68.6 & 24.7 \\
12 & 3.72 & 2.03 & 1.89 & 54.6 & 50.9 \\
1 & 3.25 & 2.24 & 1.27 & 68.9 & 49.2 \\
Mean & & & & 68.4 & 35.2 \\
SD & & & & 10.9 & 12.3 \\
\hline
\end{tabular}

with the highest rates being observed at the low nitrate-stations. Means for each size fraction at the lownitrate and high-nitrate stations are given in Table 4. Netplankton growth always exceeded nanoplankton growth on regenerated $\mathrm{N}$, and for total $\mathrm{N}$ uptake. Finally, growth rates estimated for net-phytoplankton approach and in some cases exceed the maximum expected growth rate for temperatures found in these waters (Table 4).

\section{DISCUSSION}

Ammonium and urea concentrations in unpolluted waters are usually low and variable (McCarthy 1980). Although the concentrations of both regenerated nutrients measured in this study were within ranges reported for other regions, the ratio of urea-N/ ammonium- $\mathrm{N}$ showed a notable variation. In most marine waters, urea- $N$ tends to be twice as concentrated as ammonium- $N$, and the mean urea-N/ammonium- $N$ ratio for a number of regions is 2.27 (Table 5). For stations sampled during this study, the mean ratio is 0.97 , however when ammonium was $<0.2 \mu \mathrm{M}$, the ratio of urea-N/ammonium- $\mathrm{N}$ was 1.92, and when ammonium was $>0.2 \mu \mathrm{M}$ the ratio was 0.14 . Since uptake rates are similar for both nitrogen sources, negative correlation between ambient ammonium and urea concentrations suggests a difference in the distribution of ammonium and urea producing organisms.

Table 4. Estimated phytoplankton specific growth rates

\begin{tabular}{|c|c|c|c|}
\hline Nitrogen source & Region & $\begin{array}{l}\text { Nanoplankton growth } \\
\text { Mean } \pm S D\left(d^{-1}\right)\end{array}$ & $\begin{array}{l}\text { Netplankton growth } \\
\text { Mean } \pm \mathrm{SD}\left(\mathrm{d}^{-1}\right)\end{array}$ \\
\hline \multicolumn{4}{|l|}{ Ammonium } \\
\hline & Low nitrate & $1.15 \pm 0.56$ & $2.13 \pm 1.53$ \\
\hline & High nitrate & $0.22 \pm 0.04$ & $0.39 \pm 0.25$ \\
\hline \multicolumn{4}{|l|}{ Urea } \\
\hline & Low nitrate & $0.60 \pm 0.41$ & $1.08 \pm 1.26$ \\
\hline & High nitrate & $0.04 \pm 0.01$ & $0.13 \pm 0.07$ \\
\hline \multicolumn{4}{|l|}{ Sum } \\
\hline & Low nitrate & $1.75 \pm 0.96$ & $3.21 \pm 2.38$ \\
\hline & High nitrate & $0.26 \pm 0.04$ & $0.52 \pm 0.21$ \\
\hline \multicolumn{4}{|l|}{ Nitrate } \\
\hline & Low nitrate & $0.69 \pm 0.34$ & $0.69 \pm 0.34$ \\
\hline & High nitrate & $1.13 \pm 0.30$ & $1.13 \pm 0.30$ \\
\hline \multicolumn{4}{|l|}{ Total N } \\
\hline & Low nitrate & $2.43 \pm 1.18$ & $3.89 \pm 2.48$ \\
\hline & High nitrate & $1.39 \pm 0.28$ & $1.65 \pm 0.51$ \\
\hline & & Temperature range & Expected maximum $\cdot$ \\
\hline & Low nitrate & $\left(13-17^{\circ} \mathrm{C}\right)$ & $1.94-2.53$ \\
\hline & High nitrate & $\left(10-12^{\circ} \mathrm{C}\right)$ & $1.60-1.78$ \\
\hline
\end{tabular}


Table 5. Regional comparison of the ratio of urea and ammonium in surface waters

\begin{tabular}{|lll|}
\hline Area & $\begin{array}{c}\text { Mean } \\
\text { Urea-N/ammonium-N }\end{array}$ & Reference \\
\hline Antarctic & 3.10 & Probyn \& Painting (1985) \\
Atlantic & 2.03 & Remsen et al. (1974) \\
Benguela upwelling & 2.08 & Probyn (1985) \\
California coastal waters & 1.71 & McCarthy (1972) \\
Peru upwelling & 2.75 & Remsen (1971) \\
Strait of Georgia & 1.98 & Price et al. (1985) \\
Washington coastal water & 1.35 & Dortch \& Postel (in press) \\
Oregon/Washington coastal water & & This study \\
$\mathrm{NH}_{4}^{+}<0.2 \mu \mathrm{M}$ & 1.92 & This study \\
$\mathrm{NH}_{4}^{+}>0.2 \mu \mathrm{M}$ & 0.14 & \\
\hline
\end{tabular}

Urea is considered a major form of 'regenerated' nitrogen, but urea uptake is not determined as frequently as ammonium in field studies of nitrogen utilization. Eppley \& Peterson (1979) suggested approximating ammonium plus urea uptake as 1.5 times ammonium uptake. Results of this study suggest that 1.2 times ammonium uptake may be a more appropriate approximation of regenerated nitrogen uptake for temperate coastal water. The positive correlation between urea concentrations and the urea fraction of regenerated nitrogen uptake suggests that the importance of urea as a nitrogen source is dependent on its availability. However, an additional inhibitory influence by ambient concentrations of ammonium is also evident. The slow turnover time found for urea (as compared to turnover of ammonium) in this study is consistent with other reports in the literature (e.g. Kristiansen 1983), and indicates a more rapid production and utilization of ammonium as a nitrogen source. Furthermore, relative preference indices indicate a preference for ammonium over urea at both high- and lownitrate stations and for both net- and nanoplankton.

Phytoplankton in this coastal upwelling region showed the typical dominance of netplankton in the nutrient-rich water and nanoplankton in nutrient-poor water. Highest biomass occurred at stations with intermediate ambient nitrate concentrations, and a hyperbolic relation was observed between chl/PN and nitrate concentration (Kokkinakis \& Wheeler 1987). Maximum chl/PN for each size fraction was also found in the highnutrient water. The mean chl/PN found for netplankton at high-nitrate stations $(1.83 \mu \mathrm{g} \mathrm{chl} / \mu \mathrm{mol} \mathrm{N})$ is close to ratios measured for laboratory cultures of diatoms, 2.25 (Darley 1977) and 1.52 (Chan 1980), and is consistent with our microscopical evaluation. The mean ratio for nanoplankton at high-nitrate stations $(0.84 \mu \mathrm{g} \mathrm{chl} / \mu \mathrm{mol}$ $\mathrm{N})$ was much lower and could result either from a mixture of diatoms and dinoflagellates $(0.46 \mu \mathrm{g} \mathrm{chl} /$ umol N; Chan 1980), or from a greater relative abun- dance of non-phytoplankton nitrogen in the nanoplankton fraction.

Some inferences about the relative contribution of specific algal composition, heterotrophic microorganisms, and detritus to the observed differences in mean $\mathrm{chl} / \mathrm{PN}$ at high-nitrate stations for the 2 size classes can be drawn from the results of the uptake experiments. The percentage uptake in each fraction was directly proportional to both the percentage chl and the percentage PN (Fig. 8A, B). The near-zero intercept of the uptake vs Chl regression suggests that essentially all of the nitrogen assimilation is by phytoplankton. The positive $x$-intercept of the uptake vs PN regression suggests that approximately $25 \%$ of the PN present is not assimilating regenerated nitrogen. Note that data for both net- and nanoplankton in the high-nitrate waters fall on the same curves. We conclude that particulate material in both size fractions is dominated by phytoplankton nitrogen, and that there is no major difference in the size distribution of the non-phytoplankton nitrogen in the high-nitrate waters. Furthermore, the difference in the chl/PN ratio for each size class in high-nitrate waters suggests that netplankton are enriched with chl a when compared with nanoplankton.

Contrasting results were obtained for the low-nitrate stations. No consistent relationship was observed between percentage uptake and percentage chl (Fig. $8 D)$, and different $x$-intercepts were found for each size fraction in the regression of uptake vs PN (Fig. 8C). The near-zero intercept for the netplankton suggests that nitrogen is being assimilated by all of the particulate nitrogen in this fraction, while the positive $x$-intercept for the nanoplankton fraction indicates a large component of heterotrophic and/or detrital nitrogen that is not assimilating nitrogen. Thus, we reject the null hypothesis that particulate nitrogen and chl-a have the same relative distribution between size classes in lownitrate water. 
Relative uptake of regenerated forms of nitrogen was high at low-nitrate stations and low at high-nitrate stations, regenerated production being 73 and $17 \%$, respectively, of total nitrogen production (Kokkinakis \& Wheeler 1987). However, there was no significant difference between uptake rates of regenerated forms of nitrogen at the high- and low-nitrate stations. A difference might be expected if phytoplankton in lownitrate waters were nitrogen limited. However, several lines of evidence suggest that phytoplankton in these waters are actually nitrogen-sufficient. The total concentration of inorganic nitrogen (nitrate, ammonium, and urea) was low offshore but still greater than $1 \mu \mathrm{M}$. Additionally, the ratio of saturating/trace ammonium uptake can be used as an index of nitrogen sufficiency and in nutrient-depleted waters ranges from 2.7 to 7.9 (Glibert \& McCarthy 1984). In a seasonal study of nitrogen utilization in coastal waters off Oregon, we found that the ratio of saturating/trace ammonium uptake rates averaged $1.41(\mathrm{SD}=0.33, n=4)$ for the period from June to August 1984 (Wheeler unpubl.). That observation, along with the similarity of trace and saturating urea uptake rates observed during this study, suggests that phytoplankton in this region is indeed nitrogen-sufficient. Thus, we accept the null hypothesis that there is no significant difference between uptake ( $\mu \mathrm{mol} \mathrm{l}^{-1} \mathrm{~h}^{-1}$ ) of regenerated forms of nitrogen in low- and high-nitrate waters, and note that this occurs despite the large difference in new vs regenerated nitrogen use in the 2 regions.

There was no significant difference in ammonium uptake between the 2 size classes, however uptake of urea was greater for net- than for nanoplankton in high-nitrate waters. Thus, we reject the null hypothesis that there is no difference in uptake rates between size classes for urea. The difference found in nitrogenspecific uptake rates and calculated growth rates for net- and nanoplankton also warrants comment. Fast nitrate uptake rates in high-nitrate waters which were dominated by netplankton (Kokkinakis \& Wheeler 1987), suggest that maximum uptake rates of all 3 nitrogen sources (nitrate, ammonium, and urea) are found in the netplankton rather than the nanoplankton. Probyn (1985) also found the highest nitrogen-specific uptake rates in the netplankton fractions for the Benguela upwelling region. In contrast, Glibert (1982) and Furnas (1983) report the greatest activity in the nanoplankton fraction for Vineyard Sound and Narrangansett Bay, respectively. Differences among these regions may result from variations in the portion of particulate nitrogen comprised of phytoplankton. Furthermore, the difference in maximum chl/PN ratios for the 2 size classes observed in this study indicate that comparison of nitrogen uptake rates normalized to chl a should be done with caution for analysis of size classes dominated by different types of phytoplankton

The high phytoplankton growth rates estimated from uptake rates measured during this study are also noteworthy. Most nitrate uptake appears to be by phototrophic rather than heterotrophic organisms (Wheeler \& Kirchman 1986). Nitrate-supported growth rates in the Oregon, Benguela, and Peru upwelling regions all provide reasonable estimates of phytoplankton growth rates $\left(1\right.$ to $2 \mathrm{~d}^{-1}$; Kokkinakis \& Wheeler 1987). Inclusion of ammonium-supported growth (Kokkinakis \& Wheeler 1987) and of ammonium and urea-supported growth for the net-and nanoplankton (this study) indicates relatively fast phytoplankton growth, and at times unreasonably high estimates of growth rates. As suggested previously (Kokkinakis \& Wheeler 1987), this discrepancy between maximum expected phytoplankton growth rates and estimates based on measured uptake rates may be due to heterotrophic utilization of regenerated nitrogen.

The fastest nitrogen-specific uptake rates and estimated growth rates occurred for the netplankton fraction in low-nitrate waters. It is unlikely that heterotrophic protozoans and other microzooplankton assimilate inorganic nitrogen, thus we are left to conclude that heterotrophic bacteria may play a significant role in the assimilation of inorganic nitrogen in the lownitrate waters. Furthermore, our results suggest the occurrence of considerable activity by 'attached' bacteria. Ferguson \& Rublee (1976) found that in coastal water near Cape Lookout, North Carolina, USA, most 'attached' bacteria were on particles 6 to $50 \mu \mathrm{m}$ and these comprised $40 \%$ of bacterial biomass. In addition, Albright et al. (1986) found a negative correlation between levels of chl and percentage of attached bacteria in Howe Sound, British Columbia. Thus, there is some justification for expecting greater activity of attached bacteria in the low-nitrate waters during our study.

Despite use of short-term incubations and the correction of ammonium uptake for isotope dilution, the uptake rates reported here may be underestimates. Mass balance calculations, first carried out by Laws (1984) using data of Glibert et al. (1982), show that more ammonjum leaves the dissolved phase than is recovered in particulate material. Similar mass balance calculations for the measurements made in this study indicated that the ratio of $\left[{ }^{15} \mathrm{~N}\right.$-ammonium removed from the dissolved pool] $/ !^{15} \mathrm{~N}$ assimilated into $\left.\mathrm{PN}\right]$ ranged from 1.5 to 20.0, averaging 6.8 (Kokkinakis 1987). Although the source of the discrepancy has not been resolved (Glibert et al. 1985), other evidence indicates that an underestimate of ammonium uptake may result from release of dissolved organic nitrogen (Chan \& Campbell 1978, Price et al. 1985) or utilization 
of ammonium by bacteria (Wheeler \& Kirchman 1986) which can pass through GF/F glass-fiber filters (Wheeler \& Kirchman unpubl.). The urea uptake rates reported here may also be underestimates, since methods for determination of urea isotope dilution during experimental incubations are not currently available. If urea regeneration is approximately equal to ammonium regeneration, then rates reported here are underestimates by an average of $42 \%$. Mass balance calculations for urea uptake cannot be carried out until isotopic dilution is assessed.

Conclusions drawn above are based on 'conservative' estimates of uptake rates. If the reported uptake rates underestimate acutal uptake rates, evidence for heterotrophic uptake of regenerated nitrogen sources is even stronger. Several other types of evidence provide support for the potential importance of heterotrophic utilization of inorganic nitrogen (especially ammonium). Eppley et al. (1977) found that inorganic nitrogen assimilation exceeded photosynthetic carbon assimilation and attributed the discrepancy to heterotrophic metabolism. Similarly, Laws et al. (1985) found that ammonium uptake rates were greater than predicted from photosynthetic protein synthesis. More recently, Wheeler \& Kirchman (1986) used size fractionation and inhibitor studies in coastal Atlantic waters to demonstrate the utilization of ammonium by heterotrophic bacteria. Thus, it is tempting to speculate that the discrepancies observed in mass balance calculations for ${ }^{15} \mathrm{~N}$ tracer studies may be due to inadequate measurement of heterotrophic nitrogen metabolism.

Two important challenges to be met in future studies of nitrogen utilization are (1) more accurate determination of ammonium and urea uptake rates and a resolution of the mass balance problem for ${ }^{15} \mathrm{~N}$ data, and (2) evaluation of the relative importance of ammonium uptake by autotrophic and heterotrophic microorganisms.

Acknowledgements. We are grateful to J. F. Siebenaller and F. G. Prahl for the opportunity to participate in their cruises aboard the RV 'Wecoma'. Financial support for this work was provided by grants OCE-8208873 and OCE-8308753 awarded to P. A. Wheeler by the National Science Foundation. Revision of the manuscript benefited from helpful comments provided by $\mathrm{K}$. Banse and $\mathrm{Q}$. Dortch.

\section{LITERATURE CITED}

Albright, L. J., McCrae, S. K., May, B. E. (1986). Attached and free-floating bacterioplankton in Howe Sound, British Columbia, a coastal marine fjord-embayment. Appl. environ. Microbiol. 51: 614-621

Atlas, E. L., Hager, S. W., Gordon, L. I., Park, P. K. (1971). A pracitical manual for use of the Technicon AutoAnalyzer in seawater nutrient analyses. Revised O.S.U. Tech. Report
215, Ref. 71-22, Dept of Oceanography, Oregon State University, Corvallis

Banse, K. (1982). Cell volumes, maximal growth rates of unicellular algal and ciliates, and the role of ciliates in the marine pelagial. Limnol. Oceanogr 27: 1059-1071

Chan, A. (1978). Comparative physiological study of marine diatoms and dinoflagellates in relation to irradiance and cell size. I. Growth under continuous light. J. Phycol. 14: $396-402$

Chan, A. (1980). Comparative physiological study of marine diatoms and dinoflagellates in relation to irradiance and cell size. II. Relationship between photosynthesis, growth, and carbon/chlorophyll a ratio. J. Phycol. 16: 428-4.32

Chan, Y. K., Campbell, N. E. R. (1978). Phytoplankton uptake and excretion of assimilated nitrate in a small Canadian shield lake. Appl. environ. Microbiol 35: 1052-1060

Darley, M. (1977). The chemical composition of diatoms. In: Werner, D. (ed.) The biology of diatoms. Univ. of California Press, Berkeley, p. 198-223

Dortch, Q., Postel, J. R. (in press). Phytoplankton-nitrogen interactions. In: Landry, M. R., Hickey, B. M. (eds.) Coastal oceanography of the Pacific Northwest, Wiley Interscience, New York

Eppley, R. W. (1972). Temperature and phytoplankton growth in the sea. Fish. Bull. U. S. 70: 1063-1085

Eppley, R. W. (1977). The growth and culture of diatoms. In. Werner, D. (ed.) The biology of diatoms. Univ. of California Press, Berkeley, p. 24-64

Eppley, R. W., Peterson, B. J. (1979). Particulate organic matter flux and planktonic new production in the deep ocean. Nature, Lond. 279: 210-215

Eppley, R. W., Sharp, J. H., Renger, E. H., Perry, M. J., Harrison, W G. (1977). Nitrogen assimilation by phytoplankton and other microorganisms in the surface waters of the central North Pacific ocean. Mar. Biol. 39: 111-120

Ferguson, R. L., Rublee, P. (1976). Contribution of bacteria to standing crop of coastal plankton. Limnol. Oceanogr 21. $141-144$

Fiedler, R., Proksch, G. (1975). The determination of nitrogen15 by emission and mass spectrometry in biochemical analysis: a review. Analyt. Chim. Acta 78: 1-62

Furnas, M. J. (1983). Nitrogen dynamics in lower Narrangansett Bay, Rhode Island. 1. Uptake by size-fractionated phytoplankton populations. J. Plankton Res. 5: 657-675

Glibert, P. M. (1982). Regional studies of daily, seasonal and size fraction variability in ammonium remineralization. Mar. Biol. 70: 209-222

Glibert, P. M., Lipschultz, F., McCarthy, J. J., Altabet, M. A. (1982). Isotope dilution models of uptake and remineralization of ammonium by marine plankton. Limnol. Oceanogr. 27: 639-650

Glibert, P. M., Lipschultz, F., McCarthy, J. J., Altabet, M. A. (1985). Has the mystery of the vanishing ${ }^{15} \mathrm{~N}$ in isotope dilution experiments been resolved? Limnol. Oceanogr. 30: $444-447$

Glibert, P. M., McCarthy, J. J. (1984). Uptake and assimilation of ammonium and nitrate by phytoplankton: indices of nutritional status for natural assemblages. J. Plankton Res. 6: 677-697

Goldman, J. C., Glibert, P. M. (1983). Kinetics of inorganic nitrogen uptake by phytoplankton. In: Carpenter, E. J., Capone, D. G. (eds.) Nitrogen in the marine environment. Academic Press, New York, p. 233-274

Harrison, W. G. (1978). Experimental measurements of nitrogen remineralization in coastal waters. Limnol. Oceanogr. 23: 684-694

Harrison, W G. (1983). Use of isotopes. In: Carpenter, E. J., 
Capone, D. G. (eds.) Nitrogen in the marine environment. Academic Press, New York, p. 763-807

Kokkinakis, S. A. (1987). Utilization of inorganic and organic nitrogen by phytoplankton off the Washington and Oregon coasts. M.S. thesis, Oregon State University

Kokkinakis, S. A., Wheeler, P. A. (1987). Nitrogen uptake and phytoplankton growth in temperate coastal upwelling regions. Limnol. Oceanogr. 32: 1112-1123

Kristiansen, S. (1983). Urea as a nitrogen source for the phytoplankton in the Oslofjord. Mar. Biol. 74: 17-24

LaRoche, J. (1983). Ammonium regeneration: its contribution to phytoplankton nitrogen requirements in a eutrophic environment. Mar. Biol. 75: 231-240

Laws, E. (1984). Isotope dilution models and the mystery of the vanishing ${ }^{15} \mathrm{~N}$. Limnol. Oceanogr. 29: 379-386

Laws, E. A., Harrison, W. G., DiTullio, G. R. (1985). A comparison of nitrogen assimilation rates based on ${ }^{15} \mathrm{~N}$ uptake and autotrophic protein synthesis. Deep Sea Res. 32: 85-95

Malone, T. C. (1980). Algal size. In: Morris, I. (ed.) The physiological ecology of phytoplankton. Univ. of California Press, Berkeley, p. 433-463

McCarthy, J. J. (1970). A urease method for urea in seawater. Limnol. Oceanogr. 15: 309-313

McCarthy, J. J. (1972). The uptake of urea by natural populations of marine phytoplankton. Limnol. Oceanogr. 17: $738-748$

McCarthy, J. J. (1980). Nitrogen. In: Morris, I. (ed.) The physiological ecology of phytoplankton. Univ. of California Press, Berkeley, p. 191-223

McCarthy, J. J., Taylor, W. R., Taft, J. L. (1977). Nitrogenous nutrition of the plankton in the Chesapeake Bay. I. Nutrient availability and phytoplankton preferences. Limnol. Oceanogr. 22: 996-1011
Price, N. M., Cochlan, W. P., Harrison, P. J. (1985). Time course of uptake of inorganic and organic nitrogen by phytoplankton in the Strait of Georgia: comparison of frontal and stratified communities. Mar. Ecol. Prog. Ser 27: $39-53$

Probyn, I A. (1985). Nitrogen uptake by size-fractionated phytoplankton populations in the southern Benguela upwelling system. Mar. Ecol. Prog. Ser. 22: 249-258

Probyn, T A., Painting, S. J. (1985). Nitrogen uptake by sizefractionated phytoplankton populations in Antarctic surface waters. Limnol. Oceanogr. 30: 1327-1331

Remsen, C. C. (1971). The distribution of urea in coastal and oceanic waters. Limnol. Oceanogr. 16: 732-740

Remsen, C. C., Carpenter, E. J., Schroeder, B. W. (1974). The role of urea in marine microbial ecology. In: Colwell, R. R., Morita, R. Y. (ed.) Effect of the ocean environment on microbial activities. University Park Press, Baltimore, p. 286-304

Small, L. F., Menzies, D. W. (1981). Patterns of primary productivity and biomass in a coastal upwelling region. Deep Sea Res. 28A: 123-149

Strickland, J. D. H., Parsons, T R. (1972). A practical handbook of seawater analysis, 2nd edn. Bull. Fish. Res. Bd Can. 167

Wheeler, P. A., Glibert, P. M., McCarthy, J. J. (1982). Ammonium uptake and incorporation by Chesapeake Bay phytoplankton; short-term kinetics. Limnol. Oceanogr. 27: $1113-1128$

Wheeler, P. A., Kirchman, D. L. (1986). Utilization of inorganic and organic forms of nitrogen by bacteria in marine systems. Limnol. Oceanogr. 31: 998-1009

This article was presented by Professor K. Banse; it was accepted for publication on December 30, 1987 